\title{
Systematic Review of Depression in Patients With Multiple Sclerosis And Its Relationship to Interferon $\beta$ treatment.
}

\author{
Leila Alba Palé a , Jordi León Caballero a, Berta Samsó Buxareu a, Purificación Salgado Serrano a , Víctor Pérez \\ Solà a,b \\ a Institut de Neuropsiquiatria i Addiccions. Hospital del Mar. Barcelona \\ ${ }^{\mathrm{b}}$ Centro de Investigación Biomédica en Red de Salud Mental (CIBERSAM)
}

\begin{abstract}
Background: Multiple sclerosis is a chronic disease considered the major cause of neurological disability in young adults worldwide. While depression is considered a determinant factor of impaired quality of life and poorer prognosis among patients with multiple sclerosis, it is very often dismissed and undertreated by physicians. Depression has been related to treatment with some immunomodulatory drugs, such as IFN $\beta$. Data from patients who committed suicide during the pivotal study of interferon used as a disease modifying treatment in multiple sclerosis support this association. Moreover, there is plenty of evidence of neuropsychiatric toxicity caused by the use of IFN $\alpha$ as a treatment for other medical conditions. Although this link still remains relatively unknown, the presence of warnings regarding the possible relationship between depression and IFN $\beta$ led to restriction in medical indications in these patients. The purpose of this paper is to try to understand the reasons for an increased prevalence in depression in multiple sclerosis and to examine the impact that IFN $\beta$ treatment has on their mood.

Methods: we performed a literature search on MEDLINE and Google Scholar databases applying PRISMA guidelines for systematic reviews. Studies were included if the participants were diagnosed with MS and prescribed IFN $\beta$ as the main treatment. We excluded non-english and full-text non available papers, as well as the articles where mental health was assessed exclusively as a feature of quality of life. The sample includes articles from 1980 to 2014, although filtration by year of publication was not applied and contains data from IFN $\beta-1 \mathrm{a}$ and IFN $\beta-1 \mathrm{~b}$. The Cochrane Collaboration Tool assessing risk of bias was used to determine the quality of the studies.

Results: ten studies met full criteria for inclusion and final data extraction. The articles have heterogeneity regarding the samples, the methodology used and the expression of the results. Only three studies support the evidence of a relationship between depression and interferon, which is statistically significant in some patients at the beginning of the treatment. They suggest that only patients on IFN $\beta$ treatment with a past history of depression may develop a major depression episode during the first six months. The remaining articles reviewed (including BENEFIT, BEYOND, and LTF trials) suggest the absence of an association.

Conclusion: The reviewed studies conclude that there is not a clear relationship between IFN $\beta$ and depression. A history of depression is a risk factor for developing depression during the first 6 months of treatment, nevertheless, it is not sufficient to contraindicate it. The development of new strategies is crucial for early detection of depressive symptoms. An adequate treatment can both improve the mood and deal with the neurological disease by increasing treatment adherence and interfering with inflammation. Chronic destructive brain changes and serotonergic depletion due to inflammatory factors have been proposed as the underlying cause of depression in these patients. It is suggested that these patients would have fewer functional reserve remaining to deal with stressful life events, which could precipitate a depressive disorder.
\end{abstract}

Keywords: systematic review, multiple sclerosis, depression, depressive symptoms, interferon $\beta$, relationship.

Correspondence: Leila Alba Palé

Full postal adress: passeig marítim 25-29 08003, Barcelona, Spain

E-mail address: 61317@ parcdesalutmar.cat

This research did not receive any specific grant from funding agencies in the public, commercial, or not-for-profit sectors.

Conflicts of interest: none 


\section{INTRODUCTION}

Multiple sclerosis (MS) is a chronic autoimmune inflammatory disease characterised by demyelination of the central nervous system (CNS). It is considered the most common cause of neurological disability in young and middle-aged adults. MS is thought to affect more than 2.1 million people worldwide(1) $\square(2)$.

Depression is the strongest determinant of impaired quality of life in MS patients. Lifetime prevalence of major depression has been estimated at around 50\%.(3) $\square$ This represents almost three times the rate reported in the general population, and it is specially high in young women with less than ten years of disease duration. Major depression is also associated with nonadherence to treatment and with an increased suicide risk. Depression in patients with MS is under-recognised by physicians and therefore, under-treated. Almost $67 \%$ of patients were not receiving antidepressant medications and a $33 \%$ of suicidal patients had not received psychological assistance (4).

Several immunomodulatory and immunosuppressive drugs have been approved for treating MS. IFN $\beta$ (a glycoprotein naturally secreted in response to viral infections) has proven to show beneficial effects in reducing relapse rates and delaying physical disability in relapsing-remitting multiple sclerosis (RRMS) and secondary-progressive multiple sclerosis (SPMS)(5).

A link between depression and IFN $\beta$ has been suggested based on data from the pivotal study during which five patients, all on active treatment, attempted suicide (6) $\square$. Since then, there have been cases describing patients suffering from depression after starting IFN $\beta$ treatment. This association is supported by the evidence of IFN $\alpha$ 's neuropsychiatric toxicity reported in cancer chemotherapy and chronic hepatitis (7) $\square(8) \square$.

As a result of these facts, manufacturers include warnings regarding the possible relationship between depression and IFN $\beta$ which leads to a restriction in medical indications. Thus, MS patients cannot fully enjoy the right to benefit from medical treatment. However, when this has been evaluated in clinical trials using validated rating scales, no association has been found. These discrepancies have been little explored and controversy on this topic is still present nowadays.

The aim of this article is to review the existing evidence available for IFN $\beta$ therapy causing or exacerbating depression, as well as assessing the reasons for an increased major depression prevalence amongst MS patients in order to improve knowledge on neuropsychiatric manifestations and its possible triggers. 


\section{METHODS}

\subsection{Search strategy}

We performed a literature search on MEDLINE database using the search terms: "Interferonbeta"[MeSH] OR ("Interferon beta-1b" OR "Interferon beta-1a") OR ("Interferon Type I"[MeSH] NOT "Interferon-alpha") AND Depress* AND "Multiple Sclerosis". We used the PRISMA (Preferred Reporting Items for Systematic reviews and Meta-Analyses) guidelines as a framework for our review. In addition, we examined the first 10 pages in Google Scholar using the terms Interferon-beta AND Cause AND Depression AND Multiple Sclerosis. We did not apply filtration by year of publication and studies contained data from IFN $\beta-1 \mathrm{a}$ as well as data from IFN $\beta-1 b$ treatment.

\subsection{Inclusion and exclusion criteria}

Studies were included if participants were primarily diagnosed with MS and prescribed IFN $\beta$ as a disease modifying treatment. We also included studies that compared other immunomodulatory drugs (i.e. IFN $\alpha$, glatiramer acetate) to IFN $\beta$ as an aetiological factor for depression, but excluded those where INF $\beta$ was not the main treatment. Depression symptoms were mainly evaluated with specific affective scales such as The Beck Depression Inventory (BDI) or The Hamilton Rating Scale for Depression (HRSD). However, studies regarding depression related to fatigue or using other non validated scales for depression were also considered. We excluded the articles where mental health was exclusively assessed as a feature of quality of life. Non-english papers and full-text not available articles were also excluded. If there were doubts on whether an abstract should be included for full text retrieval, it was decided that they would be included.

\subsection{Quality assessment}

The Cochrane Collaboration Tool assessing risk of bias was used to determine the quality of the studies (9) $\square$.

This is a two part tool addressing six specific domains of bias (sequence generation, allocation concealment, blinding of participants, personnel and outcome assessors, incomplete outcome data, selective outcome reporting and "other sources of bias"). Each domain includes one or more specific entries in a "risk of bias" table. Within each entry, the first part of the tool describes what was reported to have happened in the study, whereas the second part assigns a judgement to the risk of bias. This is achieved by assigning a "low risk", "high risk" or "unclear risk" of bias to each study.

\section{RESULTS AND DISCUSSION}

\subsection{Description of studies}

Initially, 119 studies were identified. After duplicates were excluded, 114 abstracts remained. All abstracts were read and 33-were selected for full text retrieval. Overall, 10 studies met full criteria for inclusion and final data extraction. A PRISMA flowchart describing the results of the search is shown in figure 1.

A description of the included studies and the most conclusive results regarding the main aim (i.e.relationship between interferon and depression) that are summarized in table 1, are discussed. 


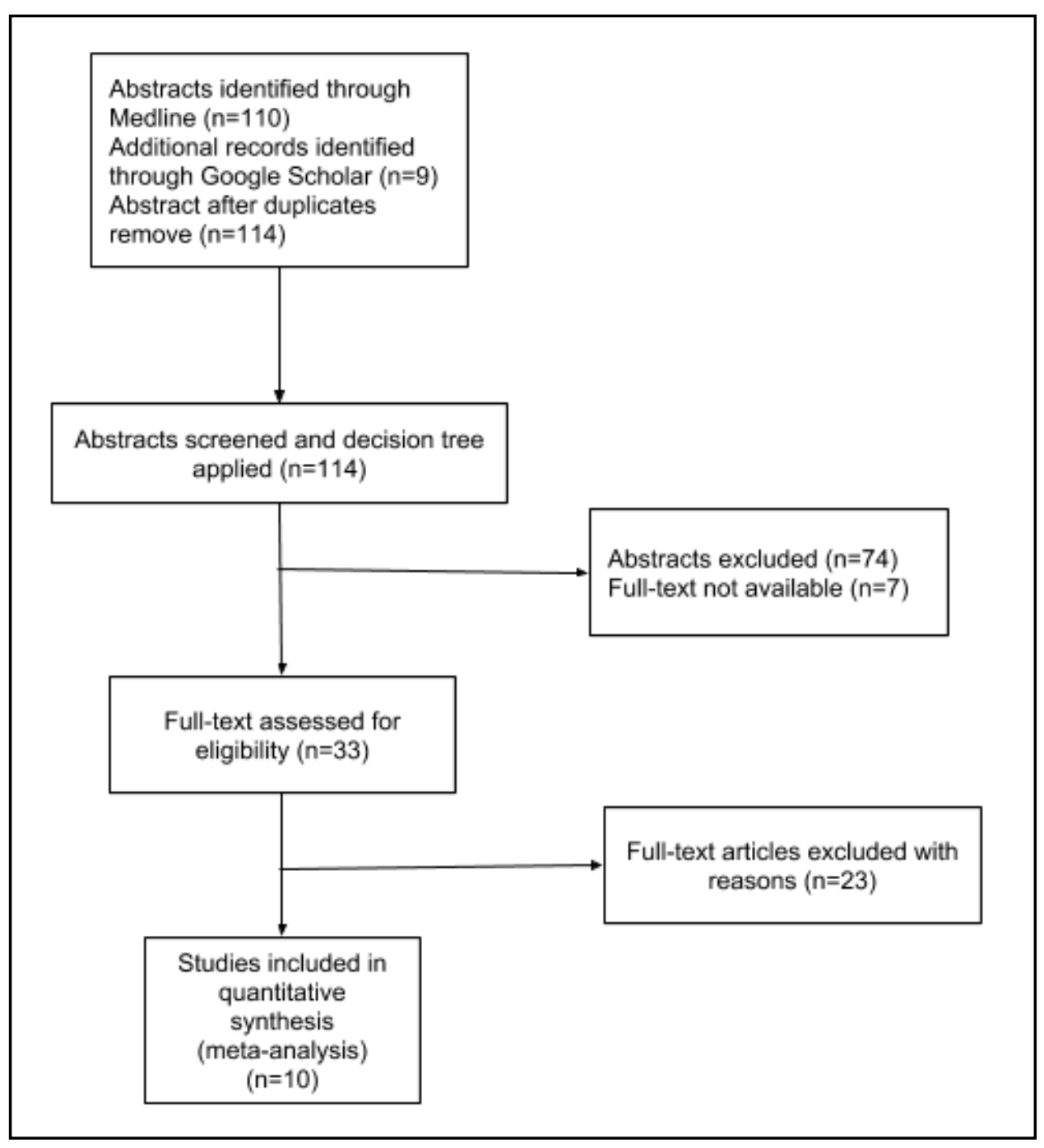

Figure 1. PRISMA flow chart detailing selection of the individual studies

\subsection{Quality assessment of studies}

After assessing the risk of bias of all the studies using the Cochrane guidelines, we found that the majority of studies had a high risk of bias in at least two of the six domains. (see table 2). All of the studies reported inadequate randomisation and concealment of allocation. Ziemssen et al.(4) $\square$ presented insufficient information to allow for any judgement. In Feinstein et al(10) $\square$ there was uncertain outcome data and was deemed high risk of bias in blinding and selective outcome reporting. In Pattern et al.(11) $\square$ the blinding and 'other' sources of bias were also high. In Siegert et al.(12) $\square$ the outcome measurement is likely to be influenced by a lack of blinding. There was also a high risk of bias in selective outcome and unclear outcome data. Insufficient information is reported in Gold et al.(13) $\square$ so it cannot be entered in a meta-analysis. 
Table 1. Details of studies reporting on Interferon use and depression

\begin{tabular}{|c|c|c|c|c|c|}
\hline Authors & Study design & IFN type & $\begin{array}{l}\text { Definition of } \\
\text { depression }\end{array}$ & $\begin{array}{l}\text { Diagnostic } \\
\text { criteria/instrument }\end{array}$ & $\begin{array}{l}\text { Association between IFN } \\
\text { and depression }\end{array}$ \\
\hline $\begin{array}{l}\text { Feinstein A } \\
(2000)^{14}\end{array}$ & $\begin{array}{l}\text { Review in MEDLINE } \\
\text { and PSYCHLIT } \\
1993-2000\end{array}$ & $\begin{array}{l}\text { IFN beta- } \\
1 \mathrm{~b}\end{array}$ & $\begin{array}{l}\text { Either a symptom or } \\
\text { syndromes of } \\
\text { varying severity }\end{array}$ & Self-Report Scales & $\begin{array}{l}\text { Low internal validity of } \\
\text { studies to draw any } \\
\text { conclusion }\end{array}$ \\
\hline $\begin{array}{l}\text { Patten S } \\
(2005)^{11}\end{array}$ & $\begin{array}{l}\text { Pooled data from } 6 \\
\text { controlled studies and } \\
17 \text { non controlled } \\
\text { clinical trials } 1995- \\
2002\end{array}$ & $\begin{array}{l}\text { IFN beta-1a } \\
\text { sc }\end{array}$ & $\begin{array}{l}\text { Aggravated } \\
\text { depression: either } \\
\text { new onset, newly } \\
\text { recognized or } \\
\text { worsened }\end{array}$ & $\begin{array}{l}\text { Physician examination } \\
\text { (DSM-IV criteria were } \\
\text { not necessarily applied) }\end{array}$ & $\begin{array}{l}\text { Statistically significant } \\
\text { association between } \\
\text { depression and IFN use } \\
\text { during the first six months of } \\
\text { treatment }\end{array}$ \\
\hline $\begin{array}{l}\text { Siegert R } \\
(2005)^{12}\end{array}$ & Review 1879-2004 & IFN beta & $\begin{array}{l}\text { Unipolar or major } \\
\text { depression }\end{array}$ & $\begin{array}{l}\text { Structured psychiatric } \\
\text { interview }\end{array}$ & $\begin{array}{l}\text { Concerns about interferon } \\
\text { treatment and depression may } \\
\text { have been undue }\end{array}$ \\
\hline $\begin{array}{l}\text { Goeb J } \\
(2006)^{15}\end{array}$ & $\begin{array}{l}\text { Review in Medline, } \\
\text { Embase and Pascal up } \\
\text { to January } 2005\end{array}$ & IFN beta & $\begin{array}{l}\text { Major depressive } \\
\text { disorder }\end{array}$ & Self-Report Scales & $\begin{array}{l}\text { No evidences of increased } \\
\text { depression in patients treated } \\
\text { with IFN }\end{array}$ \\
\hline $\begin{array}{l}\text { Ziemssen T } \\
(2009)^{4}\end{array}$ & Review 1984-2008 & IFN beta & $\begin{array}{l}\text { Major depressive } \\
\text { disorder }\end{array}$ & $\begin{array}{l}\text { Beck Depression } \\
\text { Inventory (BDI) }\end{array}$ & $\begin{array}{l}\text { IFN beta may aggravate } \\
\text { depression }\end{array}$ \\
\hline $\begin{array}{l}\text { Gold S } \\
(2009)^{13}\end{array}$ & Review 1980-2005 & $\begin{array}{l}\text { IFN beta-1a } \\
\text { and other } \\
\text { cytokines }\end{array}$ & $\begin{array}{l}\text { Depressive } \\
\text { symptoms }\end{array}$ & $\begin{array}{l}\text { Sickness behaviour } \\
\text { model }\end{array}$ & $\begin{array}{l}\text { Subtypes of MS depression } \\
\text { may be linked to } \\
\text { inflammatory markers }\end{array}$ \\
\hline $\begin{array}{l}\text { Nikfar S } \\
(2010)^{16}\end{array}$ & $\begin{array}{l}\text { Meta-analysis } 9 \\
\text { controlled trials } \\
\text { reviewed in PubMed, } \\
\text { Scopus, Cochrane } \\
\text { 1966-May } 2010\end{array}$ & IFN beta & Depression & Not mentioned & $\begin{array}{l}\text { There were no significant } \\
\text { differences in depression } \\
\text { between IFN beta and } \\
\text { placebo. }\end{array}$ \\
\hline $\begin{array}{l}\text { Feinstein A } \\
(2011)^{10}\end{array}$ & Review 1984-2011 & $\begin{array}{l}\text { IFN beta- } \\
1 \mathrm{~b}\end{array}$ & $\begin{array}{l}\text { Syndrome of major } \\
\text { depression }\end{array}$ & Clinical interview & $\begin{array}{l}\text { Poor adherence with a disease } \\
\text { modifying drug is associated } \\
\text { with depression }\end{array}$ \\
\hline $\begin{array}{l}\text { Plosker G } \\
(2011)^{17}\end{array}$ & $\begin{array}{l}\text { Review in } \\
\text { MEDLINE, } \\
\text { EMBASE and } \\
\text { AdisBase 1980-Nov } \\
2010\end{array}$ & $\begin{array}{l}\text { IFN beta- } \\
1 \mathrm{~b}\end{array}$ & Depression & Not mentioned & $\begin{array}{l}\text { Depression occurs with } \\
\text { increased frequency in } \\
\text { association with interferon } \\
\text { use }\end{array}$ \\
\hline $\begin{array}{l}\text { Reder A } \\
(2014)^{18}\end{array}$ & $\begin{array}{l}\text { Review of adverse } \\
\text { events in } 3 \text { clinical } \\
\text { trials (BENEFIT, } \\
\text { BEYOND, and the } \\
\text { 16-year Long-Term } \\
\text { Follow-up (LTF)) }\end{array}$ & $\begin{array}{l}\text { IFN beta- } \\
1 \mathrm{~b}\end{array}$ & Depression & $\begin{array}{l}\text { Mandated questions and } \\
\text { patients' self-reports }\end{array}$ & $\begin{array}{l}\text { There was not an increase in } \\
\text { rates of depression due to } \\
\text { interferon } \beta-1 b \text { treatment }\end{array}$ \\
\hline
\end{tabular}


Table 2. Quality assessment of the included studies based on risk of bias

\begin{tabular}{|c|c|c|c|c|c|c|}
\hline Study & $\begin{array}{c}\text { Sequence } \\
\text { generation }\end{array}$ & $\begin{array}{c}\text { Allocation } \\
\text { concealment }\end{array}$ & $\begin{array}{c}\text { Blinding of participants, } \\
\text { personnel and outcome } \\
\text { assessors }\end{array}$ & $\begin{array}{l}\text { Incomplete } \\
\text { outcome } \\
\text { data }\end{array}$ & $\begin{array}{l}\text { Selective } \\
\text { outcome } \\
\text { reporting }\end{array}$ & $\begin{array}{c}\text { Other sources } \\
\text { of bias }\end{array}$ \\
\hline $\begin{array}{l}\text { Feinstein A } \\
(2000)^{14}\end{array}$ & High & High & Low & Unclear & Low & Low \\
\hline $\begin{array}{l}\text { Patten S } \\
(2005)^{11}\end{array}$ & High & High & High & Low & Low & High \\
\hline $\begin{array}{l}\text { Siegert R } \\
(2005)^{12}\end{array}$ & High & High & High & Unclear & High & High \\
\hline $\begin{array}{l}\text { Goeb J } \\
(2006)^{15}\end{array}$ & High & High & High & Unclear & Low & Low \\
\hline $\begin{array}{l}\text { Ziemssen } \\
\mathrm{T}(2009)^{4}\end{array}$ & Unclear & Unclear & Unclear & Unclear & High & High \\
\hline $\begin{array}{l}\text { Gold S } \\
(2009)^{13}\end{array}$ & High & High & Unclear & Low & High & Low \\
\hline $\begin{array}{l}\text { Nikfar S } \\
(2010)^{16}\end{array}$ & High & High & Low & Low & Low & Low \\
\hline $\begin{array}{l}\text { Feinstein A } \\
(2011)^{10}\end{array}$ & High & High & High & Unclear & High & High \\
\hline $\begin{array}{l}\text { Plosker G } \\
(2011)^{17}\end{array}$ & High & High & Low & Low & Low & Low \\
\hline $\begin{array}{l}\text { Reder A } \\
(2014)^{18}\end{array}$ & High & High & Low & Low & Low & Low \\
\hline
\end{tabular}

\subsection{Interferon and depression}

One of the articles that approached the question of whether interferon induced depression for the first time was Feinsten et al.(14) $\square$. They evaluated all the publications available on the topic since 1993. The authors considered the possibility of the IFN $\beta-1 b$ having an inherent mood destabilizing effect, but highlighted the methodological weaknesses of the studies. They exposed that the use of rating scales such BDI could influence the results, as it contains numerous questions linked to somatic complaints.

Five years later, Siegert et al.(12) $\square$ reviewed similar data and concluded that, although depression should be a feature of medical management in MS patients, the relationship between interferon beta and depression had been unwarranted. They also emphasised on the importance of treating depression in these patients.

Other studies reported comparable results. For example, Goeb et al.(15) $\square$ reviewed sixteen articles about psychiatric side effects under IFN $\beta$. Fourteen articles discarded an association and one found that prevalence rates for major depression declined during treatment.

On the other hand, several authors presented data supporting the hypothesis of a relationship. 
Pattern et al.(11) $\square$ evaluated 2819 patients including patients with RRMS and SPMS. Of these, 824 received placebo and IFN $\beta$-1a was administered to 1995 . Depression was defined based on mood clinical changes detected by the treating physician. They recorded data from a six-month assessment period. Two-year and six-year data were recorded from subsets of the controlled population, comprised of 1178 patients of whom 392 were receiving placebo from 1-2 or 1-3 years and 786 were receiving interferon. During the first six months, between $5 \%$ and $18 \%$ of patients included in the treatment group reported depression compared to the $8 \%$ of patients taking placebo. Depression was a reason for abandoning therapy in $1.3 \%$ of patients receiving IFN and for only $0,6 \%$ on the placebo group. No significant differences were found among groups after two and six years of treatment. Ziemssen et al.(4) $\square$ assumed that interferon increases the risk of depression in susceptible individuals and even proposed an algorithm for its management in MS patients. They suggested an initial screening for depression using the BDI at baseline. Patients who scored $\geq 13$ on the test should undergo a deep diagnostic interview. For those with a previous history of depression or a current confirmed depressive episode, other noninterferon treatments should be chosen.

Gold et al.(13) $\square$ speak of an 'inflammatory' kind of depression. Depressive symptoms including anxiety, dysphoria, anhedonia, fatigue, anorexia, cognitive and slowness can occur after 1 to 3 months of therapy and persist unless treatment is terminated or supplemented with antidepressants. In healthy human volunteers, endogenous cytokines have been proven to develop transient neuropsychiatric symptoms. It is then conceivable that the depression observed in MS patients reflects the cytokine network activation partly triggered by interferon treatment.

Plosker et al.(17) $\square$ published an updated review of the pharmacology, clinical efficacy and tolerability of interferon in the management of patients with MS. The authors extracted data from 9 placebo controlled and active-comparator trials in RRMS and SPMS patients. Depression was reported as one of the most serious adverse effects and pointed out that it occurred with major frequency among patients using IFN $\beta-1 b$. However, they do not provide further information regarding this issue.

Recent publications indicate that IFN $\beta$ is not directly linked to depression in these patients. In 2011 Feinsten et al.(10) $\square$ established that developing depression during interferon treatment was mainly determined by a prior history of depression. They suggested that in case of depression, interferon treatment should not be discontinued.

Nikfar et al.(16) $\square$ analysed 9 randomized, double-blind trials assessing the efficacy and tolerability of interferon beta in patients with MS. Specific adverse events of interest such as depression were analyzed individually and compared between IFN $\beta$ and placebo. The accumulative relative risk for depression in three trials was 0.99 . There were no significant differences between groups.

Reder et al.(18) $\square$ reviewed results from three trials. The BENEFIT trial assessed the potencial effects of early vs. delayed treatment of $292 \mathrm{MS}$ patients receiving IFN $\beta-1$ and 176 receiving placebo. In the first 2 years, $10,3 \%$ of patients on treatment experienced depression compared to 
$11,4 \%$ in the placebo group. The BEYOND study compared efficacy, safety and tolerability of doses of $250 \mu \mathrm{g}$ of IFN $\beta-1 \mathrm{~b}$ in 887 patients, $500 \mu \mathrm{g}$ in 888 patients and in 445 patients receiving glatiramer acetate. Authors reported incidence rates of depression of $17 \%$ in both groups receiving IFN $\beta-1 \mathrm{~b}$ and $14 \%$ in those with glatiramer. The 16-year LTF study provided additional long-term follow-up for 328 patients from the original pivotal trial of IFN $\beta-1 \mathrm{~b}$ in RRMS. After two years, $42 \%$ of patients on treatment reported depression compared to $46,3 \%$ of those who were not receiving interferon.

The results from detailed and methodologically sound clinical trials assessing this association were collected and a Forest Plot was produced. Figure 2, Figure 3.

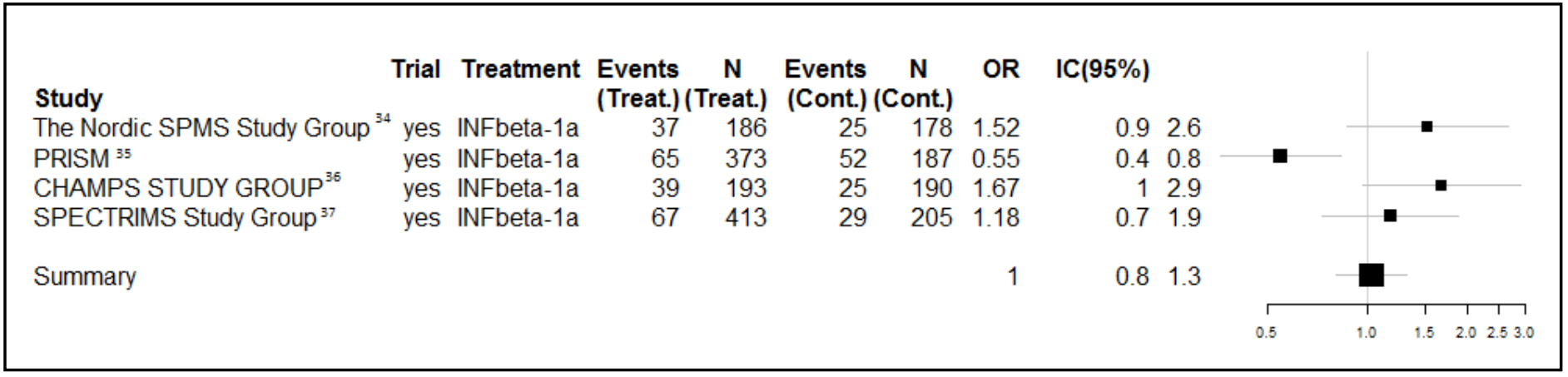

Figure 2. Forest Plot including clinical trials reporting data of incidence of depression among patients receiving treatment with interferon beta-1a treatment compared to placebo

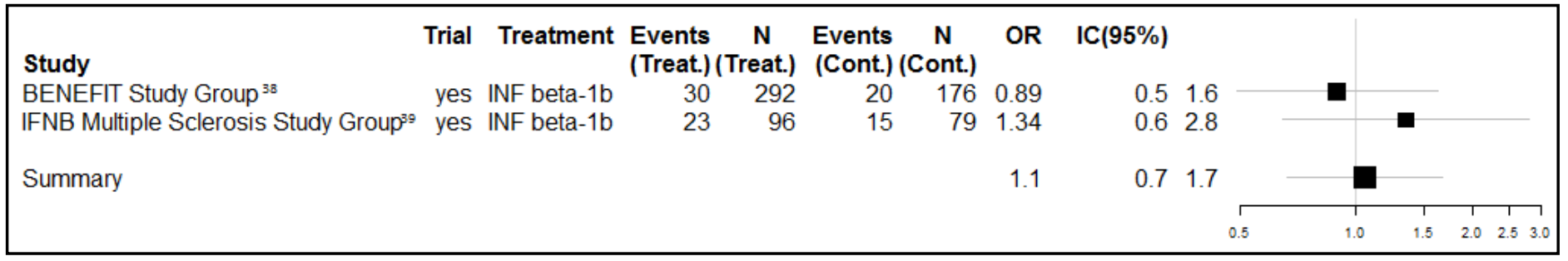

Figure 3. Forest Plot including clinical trials reporting data of incidence of depression among patients receiving treatment with interferon beta-1b compared to placebo

\subsection{Depression in multiple sclerosis}

Depression is a common and important occurrence in people with MS. Despite the afterthought that depression in these patients is primarily reactive to the diagnosis and prognosis, the heterogenous nature of the syndrome suggests that many factors are at play. No correlation has been found between disease severity and depression; and interventions to provide social support have failed to show any improvement (19) $\square(20) \square$. In addition, major depression is seen more often in MS compared to other chronic progressive diseases. (21) $\square$ Apparently, it does not seem to be a clear genetic predisposition to major depression in MS (22) $\square$. With the development of neuroimaging tests a link between depression and structural changes has been established. MS 
patients with brain lesions were more depressed than those patients with only spinal cord lesions, specially if the lesions were located in the left anterior temporal regions. Although certain relationships/links were observed, authors suggest that depression would more likely be a consequence of chronic destructive brain changes than a result of the acute hyperintense lesions. They suggest that MS patients would have fewer functional reserve remains to deal with stressful life events which could precipitate a depressive disorder. (23)(24) $\square \square$ On the other hand, the nervous system inflammation by itself could be the underlying cause of depression in MS. Metaanalyses indicate that depression is associated with an increase in circulating levels of the proinflammatory cytokine, interleukin-6, and elevated levels of this cytokine have been found in adults with major depression (25) $\square(26) \square(27) \square$. In the case of MS, the breakdown of the bloodbrain barrier may allow the entry of inflammatory cells into the CNS as well as an increased local production of cytokines as a result of the inner brain inflammation. In the last few years, it has been proposed that cytokines could produce a serotonergic depletion in CNS, and thus lead to depression.(28) $\square(29) \square(30) \square \square$ One of the studied mechanisms is the induction of indolamine-2,3-dioxygenasa (IDO), an enzyme that metabolizes tryptophan, the precursor of serotonine. Some studies have found an increased secretion of interleukine-6 and IDO stimulation due to IFN $\beta$ administration. (31) $\square(32)(33) \square$. In addition, elevated levels of corticotropin releasing hormone due to a hyperactivation of the hypothalamus pituitary adrenal axis seen in stressed and depressive patients can aggravate the inflammatory response and perpetuate the brain lesion.

The articles included in this review have heterogeneity regarding the samples, methodology used and expression of results. The samples of the studies are in many cases small, and vary according to the MS type and the IFN $\beta$ formulation. Few studies used a structured, validated clinical interview. In addition, a valid rating scale specific for mood in these patients should be developed. Alcohol and substance abuse, which is known to be closely related to major depression should be taken into account. The distinction between mild symptoms of depression and the diagnoses of depression as a whole syndrome can also influence the results.

\section{DISCUSSION}

To our knowledge, this is the first systematic review conducted to evaluate the relationship between IFN $\beta$ treatment and depression in MS patients. Although clinical trials suggest a link between IFN $\beta$ and depression, data from reviewed studies do not support this relationship.

Several narrative reviews have been published, showing contradictory results. In the first review of the topic, Feinstein (14) highlights that no conclusions can be achieved due to the weakness of the methodology of the studies. Siegert et al (12) pointed out that the relationship between IFN $\beta$ and depression had been unwarranted established. In the review conducted by Goeb et al (15) no evidence of increase in depression in MS patients treated with IFN $\beta$ was found. Similar results were found by Reder et al (18), who concluded that there was no increase in the depression rate due to IFN $\beta$-1b after reviewing data from three clinical trials. Ziemssen (4) assumed that IFN $\beta$ increased the risk of depression in susceptible individuals, but this conclusion is not based on an exhaustive review of the subject and reported that the impact of IFN $\beta$ on depression is controversial. Plosker et al (17) reviewed data from nine clinical trials and mentioned that depression was one of the most serious adverse events reported with IFN $\beta-1 b$ and that depression 
occurs with increased frequency with IFN use, but no incidence rate or increased risk rate was described.

In the analysis of pooled data from 6 controlled studies and 17 non controlled studies, Patten et al (11) concluded a statistically significant association between depression and IFN use within the 6 initials months of treatment, however, no significant differences were found among groups after two nor six years of treatment.

The best methodological study available is the meta-analysis of 9 controlled trials conducted by Nifkar et al (16), and no significant difference in depression rate was found between the IFN $\beta$ and placebo group.

The conducted forest plot supports data showing a lack of association between interferon beta and depression in the articles reviewed. The results are more robust for interferon beta-1a than for interferon beta-1b, as more homogeneous interferon beta-1a clinical trials assessing this issue are available in the literature.

\section{CONCLUSIONS}

As mentioned above, data from our systematic review does not support a clear link between treatment with IFN $\beta$ and depression. Only a history of depression has been found to be a risk factor for developing depression in MS patients. According to the available data, it seems controversial to contraindicate IFN $\beta$ treatment in MS patients. A close follow-up of patients with a history of depression is recommended when they undergo treatment with IFN $\beta$. Cooperation between a neurologist and a psychiatrist is required in order to detect major depression. Designing new specific structured interviews and counseling patients that depression may develop can help to recognise depressive symptoms early on in the course of the disease. While untreated depression in these patients is likely to worsen, it is particularly responsive to the use of antidepressants. Antidepressant treatment is believed to decrease inflammatory markers. Detecting and treating depression not only may reduce the inflammatory process, but could also increase the patient's compliance with a disease modifying drug, which has proved efficacy in slowing down the progression of the disease. Nevertheless, we are aware that methodological limitations prevent from drawing definite conclusions on these issues and we encourage authors to carry out further investigation.

\section{REFERENCES}

1. World Health Organization MSIF. Atlas: multiple sclerosis resources in the world. World Health Organization. 2008.

2. Confavreux C, Vukusic S, Moreau T, Adeleine P. Relapses and progression of disability in multiple sclerosis. N Engl J Med [Internet]. 2000 Nov 16 [cited 2016 Jun 30];343(20):1430-8. Available from: http://www.ncbi.nlm.nih.gov/pubmed/11078767

3. Sadovnick AD, Remick RA, Allen J, Swartz E, Yee IM, Eisen K, et al. Depression and multiple sclerosis. Neurology [Internet]. 1996 Mar [cited 2016 Jun 30];46(3):628-32. Available from: http://www.ncbi.nlm.nih.gov/pubmed/8618657 
4. Ziemssen T. Multiple sclerosis beyond EDSS: depression and fatigue. J Neurol Sci [Internet]. Elsevier; 2009 Feb 1 [cited 2016 Feb 1];277:S37-41. Available from: http://www.jns-journal.com/article/S0022510X09700115/fulltext

5. Goodin DS, Frohman EM, Garmany GP, Halper J, Likosky WH, Lublin FD, et al. Disease modifying therapies in multiple sclerosis: report of the Therapeutics and Technology Assessment Subcommittee of the American Academy of Neurology and the MS Council for Clinical Practice Guidelines. Neurology [Internet]. 2002 Jan 22 [cited 2016 Jun 30];58(2):169-78. Available from: http://www.ncbi.nlm.nih.gov/pubmed/11805241

6. Interferon beta- $1 \mathrm{~b}$ in the treatment of multiple sclerosis: final outcome of the randomized controlled trial. The IFNB Multiple Sclerosis Study Group and The University of British Columbia MS/MRI Analysis Group. Neurology [Internet]. 1995 Jul [cited 2016 Apr 9];45(7):1277-85. Available from: http://www.ncbi.nlm.nih.gov/pubmed/7617182

7. Majer M, Welberg LAM, Capuron L, Pagnoni G, Raison CL, Miller AH. IFN-alphainduced motor slowing is associated with increased depression and fatigue in patients with chronic hepatitis C. Brain Behav Immun [Internet]. 2008 Aug [cited 2016 Apr 10];22(6):870-80. Available from: http://www.pubmedcentral.nih.gov/articlerender.fcgi?artid=2497339\&tool=pmcentrez\&re ndertype $=$ abstract

8. Patten SB, Barbui C. Drug-induced depression: a systematic review to inform clinical practice. Psychother Psychosom [Internet]. Jan [cited 2016 Apr 10];73(4):207-15. Available from: http://www.ncbi.nlm.nih.gov/pubmed/15184715

9. Higgins JPT, Altman DG, Gøtzsche PC, Jüni P, Moher D, Oxman AD, et al. The Cochrane Collaboration's tool for assessing risk of bias in randomised trials. BMJ [Internet]. 2011 Jan 18 [cited 2014 Jul 10];343(oct18_2):d5928. Available from: http://www.bmj.com/content/343/bmj.d5928.abstract

10. Feinstein A. Multiple sclerosis and depression. Mult Scler [Internet]. 2011 Nov 1 [cited 2015 Dec 13];17(11):1276-81. Available from: http://msj.sagepub.com/content/17/11/1276.short

11. Patten SB, Francis G, Metz LM, Lopez-Bresnahan M, Chang P, Curtin F. The relationship between depression and interferon beta-1a therapy in patients with multiple sclerosis. Mult Scler [Internet]. 2005 Apr 1 [cited 2016 Feb 14];11(2):175-81. Available from: http://msj.sagepub.com/content/11/2/175.short

12. Siegert RJ, Abernethy DA. Depression in multiple sclerosis: a review. J Neurol Neurosurg Psychiatry [Internet]. 2005 Apr 1 [cited 2015 Dec 13];76(4):469-75. Available from: http://jnnp.bmj.com/content/76/4/469.short

13. Gold SM, Irwin MR. Depression and immunity: inflammation and depressive symptoms in multiple sclerosis. Immunol Allergy Clin North Am [Internet]. 2009 May [cited 2016 Feb 1];29(2):309-20. Available from: http://www.pubmedcentral.nih.gov/articlerender.fcgi?artid=3625861\&tool=pmcentrez\&re 
ndertype $=$ abstract

14. Feinstein A. Multiple sclerosis, disease modifying treatments and depression: a critical methodological review. Mult Scler [Internet]. 2000 Oct [cited 2016 Mar 6];6(5):343-8. Available from: http://www.ncbi.nlm.nih.gov/pubmed/11064445

15. Goeb J-L, Even C, Nicolas G, Gohier B, Dubas F, Garré JB. Psychiatric side effects of interferon-beta in multiple sclerosis. Eur Psychiatry [Internet]. 2006 Apr [cited 2016 Feb 14];21(3):186-93. Available from: http://www.sciencedirect.com/science/article/pii/S0924933805001744

16. Nikfar S, Rahimi R, Abdollahi M. A meta-analysis of the efficacy and tolerability of interferon- $\beta$ in multiple sclerosis, overall and by drug and disease type. Clin Ther [Internet]. 2010 Oct [cited 2016 Feb 29];32(11):1871-88. Available from: http://www.ncbi.nlm.nih.gov/pubmed/21095482

17. Plosker GL. Interferon- $\beta-1 b$ : a review of its use in multiple sclerosis. CNS Drugs [Internet]. 2011 Jan [cited 2016 Mar 4];25(1):67-88. Available from: http://www.ncbi.nlm.nih.gov/pubmed/21128695

18. Reder AT, Oger JF, Kappos L, O'Connor P, Rametta M. Short-term and long-term safety and tolerability of interferon $\beta-1 \mathrm{~b}$ in multiple sclerosis. Mult Scler Relat Disord [Internet]. 2014 May [cited 2016 Feb 25];3(3):294-302. Available from: http://www.ncbi.nlm.nih.gov/pubmed/25876467

19. Möller A, Wiedemann G, Rohde U, Backmund H, Sonntag A. Correlates of cognitive impairment and depressive mood disorder in multiple sclerosis. Acta Psychiatr Scand [Internet]. 1994 Feb [cited 2016 Apr 13];89(2):117-21. Available from: http://www.ncbi.nlm.nih.gov/pubmed/8178661

20. Messmer Uccelli M, Mancuso Mohr L, Battaglia MA, Zagami P, Mohr DC. Peer support groups in multiple sclerosis: current effectiveness and future directions. Mult Scler [Internet]. 2004 Feb [cited 2016 Apr 13];10(1):80-4. Available from: http://www.ncbi.nlm.nih.gov/pubmed/14760957

21. Patten SB, Beck CA, Williams JVA, Barbui C, Metz LM. Major depression in multiple sclerosis: a population-based perspective. Neurology [Internet]. 2003 Dec 9 [cited 2016 Jun 30];61(11):1524-7. Available from: http://www.ncbi.nlm.nih.gov/pubmed/14663036

22. Joffe RT, Lippert GP, Gray TA, Sawa G, Horvath Z. Personal and family history of affective illness in patients with multiple sclerosis. J Affect Disord [Internet]. Jan [cited 2016 Apr 13];12(1):63-5. Available from: http://www.ncbi.nlm.nih.gov/pubmed/2952696

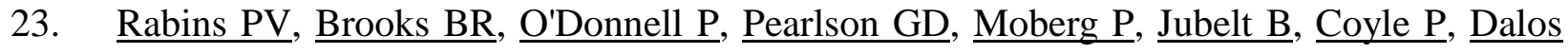
$\underline{\mathrm{N}}$, Folstein MF. Structural brain correlates of emotional disorder in multiple sclerosis. Brain : a journal of neurology. 1986 vol: 109 ( Pt 4) pp: 585-97. Available from: www.ncbi.nlm.nih.gov/pubmed/3730806

24. Passamonti L, Cerasa A, Liguori M, Gioia MC, Valentino P, Nisticò R, et al. 
Neurobiological mechanisms underlying emotional processing in relapsing-remitting multiple sclerosis. Brain [Internet]. 2009 Dec [cited 2016 Jun 30];132(Pt 12):3380-91. Available from: http://www.ncbi.nlm.nih.gov/pubmed/19420090

25. Motivala SJ, Sarfatti A, Olmos L, Irwin MR. Inflammatory markers and sleep disturbance in major depression. Psychosom Med [Internet]. Jan [cited 2016 Apr 13];67(2):187-94. Available from: http://www.ncbi.nlm.nih.gov/pubmed/15784782

26. Pike JL, Irwin MR. Dissociation of inflammatory markers and natural killer cell activity in major depressive disorder. Brain Behav Immun [Internet]. 2006 Mar [cited 2016 Apr 13];20(2):169-74. Available from: http://www.ncbi.nlm.nih.gov/pubmed/16023828

27. Frommberger UH, Bauer J, Haselbauer P, Fräulin A, Riemann D, Berger M. Interleukin-6(IL-6) plasma levels in depression and schizophrenia: comparison between the acute state and after remission. Eur Arch Psychiatry Clin Neurosci [Internet]. 1997 Jan [cited 2016 Apr 13];247(4):228-33. Available from: http://www.ncbi.nlm.nih.gov/pubmed/9332905

28. Maes M1, Verkerk R, Bonaccorso S, Ombelet W, Bosmans E SS, 1Department of Psychiatry, University Hospital of Maastricht, Postbus 5800, 6202 AZ Maastricht TN crcmh@online. b. Depressive and anxiety symptoms in the early puerperium are related to increased degradation of tryptophan into kynurenine, a phenomenon which is related to immune activation. Life Sci. 2002;71(16):1837-48.

29. Amirkhani A, Heldin E, Markides KE, Bergquist J. Quantitation of tryptophan, kynurenine and kynurenic acid in human plasma by capillary liquid chromatographyelectrospray ionization tandem mass spectrometry. J Chromatogr B [Internet]. 2002 Nov [cited 2016 Jun 30];780(2):381-7. Available from: http://linkinghub.elsevier.com/retrieve/pii/S157002320200572X

30. Orlikov AB, Prakhye IB, Ryzov I V. Kynurenine in blood plasma and DST in patients with endogenous anxiety and endogenous depression. Biol Psychiatry [Internet]. 1994 Jul [cited 2016 Jun 30];36(2):97-102. Available from: http://linkinghub.elsevier.com/retrieve/pii/0006322394911894

31. Amirkhani A, Rajda C, Arvidsson B, Bencsik K, Boda K, Seres E, et al. Interferon-beta affects the tryptophan metabolism in multiple sclerosis patients. Eur J Neurol [Internet]. 2005 Aug [cited 2016 Apr 13];12(8):625-31. Available from: http://www.ncbi.nlm.nih.gov/pubmed/16053472

32. Brod SA, Marshall GD, Henninger EM, Sriram S, Khan M, Wolinsky JS. Interferon-beta $1 \mathrm{~b}$ treatment decreases tumor necrosis factor-alpha and increases interleukin-6 production in multiple sclerosis. Neurology [Internet]. 1996 Jun [cited 2016 Apr 13];46(6):1633-8. Available from: http://www.ncbi.nlm.nih.gov/pubmed/8649562

33. Amirkhani A, Rajda C, Arvidsson B, Bencsik K, Boda K, Seres E, et al. Interferon-beta affects the tryptophan metabolism in multiple sclerosis patients. Eur J Neurol [Internet]. 2005 Aug [cited 2016 Jun 30];12(8):625-31. Available from: http://www.ncbi.nlm.nih.gov/pubmed/16053472 
34. Andersen O, Elovaara I, Färkkilä M, Hansen HJ, Mellgren SI, Myhr K-M, et al. Multicentre, randomised, double blind, placebo controlled, phase III study of weekly, low dose, subcutaneous interferon beta-1a in secondary progressive multiple sclerosis. J Neurol Neurosurg Psychiatry [Internet]. 2004 [cited 2017 May 16];75:706-10. Available from: https://www.ncbi.nlm.nih.gov/pmc/articles/PMC1763573/pdf/v075p00706.pdf

35. Randomised double-blind placebo-controlled study of interferon beta-1a in relapsing/remitting multiple sclerosis. PRISMS (Prevention of Relapses and Disability by Interferon beta-1a Subcutaneously in Multiple Sclerosis) Study Group. Lancet (London, England) [Internet]. 1998 Nov 7 [cited 2017 May 16];352(9139):1498-504. Available from: http://www.ncbi.nlm.nih.gov/pubmed/9820297

36. Jacobs LD, Beck RW, Simon JH, Kinkel RP, Brownscheidle CM, Murray TJ, et al. Intramuscular Interferon Beta-1A Therapy Initiated during a First Demyelinating Event in Multiple Sclerosis. N Engl J Med [Internet]. 2000 Sep 28 [cited 2017 May 16];343(13):898-904. Available from: http://www.ncbi.nlm.nih.gov/pubmed/11006365

37. Secondary Progressive Efficacy Clinical Trial of Recombinant Interferon-Beta-1a in MS (SPECTRIMS) Study Group. Randomized controlled trial of interferon- beta-1a in secondary progressive MS: Clinical results. Neurology [Internet]. 2001 Jun 12 [cited 2017 May 16];56(11):1496-504. Available from: http://www.ncbi.nlm.nih.gov/pubmed/11402106

38. Kappos L, Polman CH, Freedman MS, Edan G, Hartung HP, Miller DH, et al. Treatment with interferon beta-1b delays conversion to clinically definite and McDonald MS in patients with clinically isolated syndromes. Neurology [Internet]. Lippincott Williams \& Wilkins; 2006 Oct 10 [cited 2017 May 16];67(7):1242-9. Available from: http://www.ncbi.nlm.nih.gov/pubmed/16914693

39. Interferon beta-1b is effective in relapsing-remitting multiple sclerosis. I. Clinical results of a multicenter, randomized, double-blind, placebo-controlled trial. The IFNB Multiple Sclerosis Study Group. Neurology [Internet]. 1993 Apr [cited 2017 May 17];43(4):65561. Available from: http://www.ncbi.nlm.nih.gov/pubmed/8469318 